\title{
Examining Leadership and Knowledge Sharing Role on Small and Medium Enterprises Innovation Capabilities
}

\author{
J.P. Kambey ${ }^{1}$, N.F. Wuryaningrat ${ }^{2}$, L.I. Kumajas ${ }^{3}$
}

\begin{abstract}
:
The inovation capability of a firm depends on knowledge resources. Knowledge sharing is an important part in knowledge management to optimize firm knowledge resources. However, knowledge sharing can not be automatically achieved. Leadership factor is an important factor to encourage knowledge sharing.

The purpose of this study was to examine the role of transformational and transactional leadership of the owners of SMEs to encourage knowledge sharing activity which in turn this activity can enhance innovation capability. The survey was conducted in the SME production sector in North Sulawesi Province, Indonesia. The research involved 176 samples. Data were analyzed with Structural Equation Model based on PLS-SEM variant.

The result showed that only transformational leadership had a positive effect to encourage knowledge sharing. Further, the result showed that knowledge donating had the positive effect to enhance innovation capability. Surprisingly, the result showed that knowledge collecting had a negative effect to innovation capability.
\end{abstract}

Keywords: Innovation capabilities, knowledge sharing, leadership style.

\footnotetext{
${ }^{1}$ Doctor of Management, Faculty of Economics Universitas Negeri Manado, Management Department. joseph.kambey@unima.ac.id

${ }^{2}$ Corresponding authors. Faculty of Economics Universitas Negeri Manado, Management Department.nikolas.fajar@unima.ac.id

${ }^{3}$ Management Department, Faculty of Economics Universitas Negeri Manado. lydia.kumajas@unima.ac.id
} 


\section{Introduction}

The capability of a firm to produce innovative commercial ends depends on the ability to manage its knowledge resources (Darroch, 2005). An effective knowledge management serves as a strategic approach which can be done by a firm to increase its benefit and gain its sustainability. Managing knowledge must be conducted in a precise way.

Knowledge sharing as a part of knowledge management is a crucial activity to effectively use the organizational resources (e.g. knowledge) (Argote et al., 1999; Srivastava et al., 2006). In many cases, the activities of knowledge sharing and/or transfer do not occur accidently. Szulanski (1996; 2000) emphasizes that barriers in sharing or transferring knowledge is mainly based on the characteristics of senders and receivers of knowledge. To overcome the barriers, the role of leader (i.e. leadership) in the organization is necessary to ensure that the process of knowledge sharing/transfer goes in an effective way (Srivastava et al., 2006). To clarify the idea, this research was conducted on the Small-Medium Enterprises (SMEs) with a number of reasons. First, management of SMEs is usually held by one person who acts as owner and manager (Stanworth and Curran, 1976; Indarti 2010). It makes the owner or manager a major actor in the development of employees and companies. Due to this perspective, this study intends to examine a better leadership role than in larger companies. In addition, only few research focus on the relationship between transformational and transactional leadership in the knowledge management (Crawford, 2005).

This study has similar topic as the previous research conducted by Wuryaningrat et al., 2012. However, this research gives more emphasis on the role of transformational and transactional leaderships on knowledge sharing and innovation capabilities on a newly developing area (North Sulawesi). Wuryaningrat et al. (2012) conducted a research on the development of SMEs in the more developing region than North Sulawesi.

\section{Literature Review and Hypothesis Development}

\subsection{Knowledge Sharing}

According to Dalkir (2005) knowledge sharing is a social activity. This activity needs attitude, behavior, and motivation to encourage knowledge sharing creation (Xue et al., 2011; Liao et al., 2007). Without knowledge sharing, the development of knowledge will be under-utilized (Srivastava et al., 2006). Knowledge sharing can be defined as tacit or explicit knowledge exchange process to make new knowledge possible (Hoof dan Ridder, 2004). Knowledge sharing includes activity to give idea, suggestion, information, experience and skill to other team members (Hoof and Rider, 2004; Bartol and Srivastava, 2002; Davenport and Prusak, 1998). According to Hoof and Rider (2004) knowledge sharing is divided in two distinct dimensions 
namely knowledge collecting and donating. Knowledge donating is a process to carry or give knowledge through communication between individual or group people. Knowledge collecting can be defined as process to have knowledge from other person through consultation or persuation to make other people wiling to share his knowledge.

Knowledge sharing is the key of success to translate individual learning to organizational capability (Frey and Oberholzer-Gee, 1997; Nahapiet and Ghoshal, 1998; Lam and Lambermont-Ford, 2008). Lam and Lambermont-Ford (2008) remind that knowledge sharing is not easy to do because it depends on individual willingness to share. This problem, according to Szulanski (1996; 2000), is called stickiness of knowledge. Therefore knowledge sharing needs other factors, one of which is a leader and his leadership (Srivastava et al., 2006).

\subsection{Innovation as Newness}

Innovation has various definitions, but it can be concluded that innovation refers to newness. According to Johannessen et al. (2001), innovation is a newness to create and to maintain sustainable compititiveness. Innovation is not only a physical application but also a process. According to Samson (1991) and Harrison and Samson (2002) innovation as newness is classified into three types: innovation product, innovation process and innovation managerial and system.

In this context, newness refers to what one company is able to deliver while other companies can not (Johannessen et al., 2001; Tidd et al., 2005). Innovation as newness refers to changes which can be regarded as innovation degree. Due to its degree, March (1991) classifies innovation into two types: exploitative innovation and exploration innovation. Tidd et al. (2005) also reveal degree of newness by classifying it into incremental innovation and radical innovation.

Sometimes, the changes can be easily accepted, but in some cases the change goes in a radical way and makes substantial reformation for an organisation (Tidd et al., 2005). For example, when a small firm uses technology information for production process, it will undergo rapid changes which affect the firm's environment. However, the use of technology information does not become a new thing for largescale companies. Innovation needs used knowledge and new knowledge from many sources. Costumers, suppliers, universities and research institutions are the sources of knowledge for organization (Indarti, 2010). Sveiby (2001) reveals that new knowledge can be obtained from internal and external sources. New knowledge gives a positive impact to innovation capability and firm performance (Tsai, 2001).

SMEs has many problems to deal with such as low capital, low human resources level and low interest from government; however, SMEs have a potential to develop their innovation capability through their knowledge. SMEs with small number employees and simple organization structure and less involvement with government 
birocracy has the advantage to absorb and share knowledge. This advantage also gives a positive impact to increase SMEs innovation capability (Ayyagari, 2006; Pelham, 2000).

\subsection{Transformational and Transactional Leaderships on Knowledge Sharing}

Transformational and transactional leaderships are two distinct qualities which a leader must possess. In other words, those terms are inclusive and share similar characteristics (Bass, 1985; Yukl, 2006). They support and strengthen each other (Hater and Bass, 1988; Den Hartog 1997). The relationship between transformational and transactional leadership in knowledge sharing can be understood as the social activity which require noble attitude and behavior as well as strong motivation from all organization members (Xue et al., 2010; Liao et al., 2007). This opinion is supported by Deluga (1990) who states that transformational and transactional leadership styles are effective to change employees' behavior.

Bass (1985; 1990) and Yukl (2006) claimed that transformational leadership is leaders' way to motivate employees to accelerate their performance, so it will exceed expection. They classifyied four dimensions of transformational leadership into individual motivation, individual inspiration, individual consideration and intellectual stimulus.

A transformational leader tries to obtain his influence and power with individual approach to inspire his employees (Yukl, 2006). Therefore, the relationship between supervisor and subordinates turns into an emotional relationship which eventually builds trust between them. According to Davenport and Prusak (1998) trust is an important factor for a person to share knowledge. Through emotional relationship, it is expected that employees open themselves and have active participation in both knowledge collecting and knowledge donating. For example, emotional relationship can be described as kinship, brotherhood or friendship. In other words transformational leadership will build supervisor-subordinate relationship as if they were family (Deluga, 1990).

A strong emotional relationship between supervisor and subordinates enables the owners of SMEs to encourage the employees to involve in the development of the company by using knowledge development. An emotional relationship becomes the underlying reason for employees to willingly share their knowledge. It can be concluded, thus, that the owners or managers of SMEs having transformational leadership have the ability to change employees' attitude and behavior. As a result, they will share knowledge and foster the activities of knowledge sharing. This opinion is supported by Bryant (2003) and Crawford (2005) who have provided empirical evidences that transformational leadership has a positive influence to knowledge management and knowledge sharing. Based on the explanation above, the research hypothesis can be formulated as follows: 
Hla : Leadership transformational positively influences knowledge collecting.

$H 1 b$ : Leadership transformational positively influences knowledge donating.

Unlike transformational leadership, transactional leadership shapes a business relationship between supervisor-subordinates. When showing transactional leadership, a leader considers employees' knowledge as the property of the company. Deluga (1990) reveals that information and skill serve as a negotiation tool to reach working agreement.

Bass (1985) and Yukl (2006) defined transactional leadership as a transaction process between supervisor and subordinates. According to Deluga (1990), transactional leadership considers the supervisor and his subordinates as the implicit or explicit working agreement. Deluga (1990) also explains that the employees receive reward or incentive when following this working agreement. On the other hand, they will receive punishment when breaking the agreement. Bass $(1985 ; 1990)$ and Yukl (2006) classifyied transactional leadership style into two dimensions, those are, contingent reward and management exception. Contingent rewards involve additional rewards to increase employees' motivation. Management exception can be explained as corrective or evalution approach from a leader to evaluate employees' performance.

According to Bock and Kim (2002), knowledge sharing can be described as the economic exchange theory. This means that knowledge sharing depends on cost and benefits made by the employees. Bartol and Srivastava (2002) explained that good extrinsic reward system such as salary raise, bonus and incentive encourage knowledge sharing. In other words Bartol and Srivastava (2002) regard reward as stimulus for employees to develop knowledge through knowledge sharing.

Related to the previous opinion above, it can be stated that transactional leadership enables a leader to extend the influence and power through instrumental compliance (Yukl, 2006). For example, a leader can extend his power and influence with salary raise, promotion and punishment given when an employee makes a mistake (Yukl, 2006). Bock and Kim (2002) argued that reward and punishment serve as the common approach for a firm to encourage knowledge sharing. Those opinions can be ilustarated as the relationship between teacher and student. When a teacher gives homework, student will do the homework for two reasons. First, they want to get a good score, and second, they avoid punishment. Due to the explanation, it can be stated that employees will receive extra benefits such as promotion and career development if they fulfill what the management wants including knowledge sharing activity. Otherwise, they will receive punishment from the management (Yukl, 2006; Bass et al., 2003). Thus, the research hypothesis can be formulated as follows:

H2a:Transactional leadership positively influences knowledge collecting. $H 2 b$ : Transactional leadership positively influences knowledge donating. 


\subsection{Knowledge Sharing and Innovation Capabilities}

Innovation is closely linked with Nonaka and Takeuchi (1995) concept about knowledge creation. The ability of a firm to manage knowledge resources can be used for finding problem solution faster. Many previous studies gave empirical evidence that knowledge sharing can enhance innovation capability (Lin, 2007; Liao et al., 2006; Darroch, 2005; Srivastava et al., 2006; Tsai, 2001, Wuryaningrat, 2013). The innovation capability of a firm resulting from knowledge sharing activity can be measured by the creation of more creative ideas. These new ideas facilitate innovation activity and new business opportunity (Darroch, 2005). As mentioned before, the purpose of knowledge is to create new knowledge from internal and external sources. Thereby, to accomplish knowledge sharing, a small firm or a larger firm should have more engagement on knowledge sources such as customers, suppliers or other sources. Thus, the research hypothesis can be formulated as follows:

H4a: Knowledge donating positively influences innovation capability.

$H 4 b$ : Knowledge collecting positively influences innovation capability.

Research hypotheses explained above serve as the basis for creating the research model. This research model consists of five variables. Leadership style and knowledge sharing form exogeneous variables whereas innovation capability forms endogeneous variables. Figure 1 shows the research model:

Figure 1. Research Model

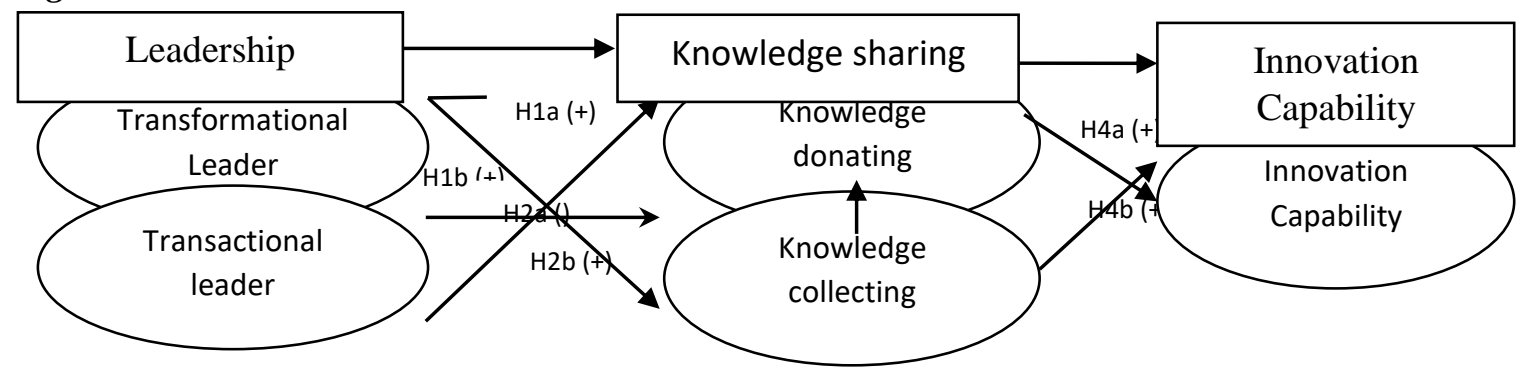

\section{Research Method}

Two hundrend questionnaires were directly distributed to the respondents. 188 questionnaires were returned, but only 176 can be analyzed because some data were missing or some did not meet the requirements set. Cross sectional survey was conducted at SMEs production sector located in North Sulawesi Province. Samples were selected based on three criteria: SMEs from production sector, SMEs production sector with minimum three-year production and SMEs with 5 to 99 employees. The owners or managers of SMEs are the major actors who take responsibilities to develop SMEs and sustain firm innovation (Stanworth and Curran, 1976; Indarti, 2010). Hence, the owner or manager of SMEs can provide 
valuable information. The research was conducted at North Sulawesi Province. Respondents' profile can be seen in Table 1.

Table 1. Respondent and Business Profiles

\begin{tabular}{|c|c|c|}
\hline Dimension & Categories & $\mathrm{N}$ \\
\hline \multirow{2}{*}{ Sex : } & a. Man & 100 \\
\hline & b. Woman & 76 \\
\hline \multirow{5}{*}{ Ages } & a. $<25$ year & 5 \\
\hline & b. 26-30 year & 18 \\
\hline & c. $31-35$ year & 16 \\
\hline & d. $36-40$ year & 95 \\
\hline & e. $>40$ year & 42 \\
\hline \multirow{6}{*}{ Education Level } & a. Elementary School & 17 \\
\hline & b. Junior High School & 37 \\
\hline & c. High School & 70 \\
\hline & d. Diploma & 8 \\
\hline & e. S1 (Under graduate) & 43 \\
\hline & f. Others (S2) & 1 \\
\hline \multirow{5}{*}{ Type of business } & a. Handy craft and General & 52 \\
\hline & b. Chemical and materials & 0 \\
\hline & c. Metal and electric & 34 \\
\hline & d. Food & 60 \\
\hline & e. Clothing and leather & 30 \\
\hline \multirow{3}{*}{ Location } & a. Village & 96 \\
\hline & b. Town & 66 \\
\hline & c. Suburban area & 14 \\
\hline \multirow{2}{*}{ Mean Number of employee } & a. Full time & 11 \\
\hline & b. Part time & 13 \\
\hline \multirow{5}{*}{ Amount of Asset (last 2 years) } & a. less than 5 milion & 59 \\
\hline & b. 5 milion $\mathrm{s} / \mathrm{d} 50$ milion & 89 \\
\hline & c. $>50 \mathrm{~s} / \mathrm{d} 100$ milion & 13 \\
\hline & d. $>100 \mathrm{~s} / \mathrm{d} 150$ milion & 5 \\
\hline & e. $>150$ milion & 10 \\
\hline \multirow{4}{*}{ Salary per month } & a. $<50$ milion & 108 \\
\hline & b. $>50 \mathrm{~s} / \mathrm{d} 100$ milion & 37 \\
\hline & c. $>100 \mathrm{~s} / \mathrm{d} 150$ milion & 21 \\
\hline & d. $>150$ milion & 10 \\
\hline
\end{tabular}

Source: Primary Data (2017).

The profiles show that the respondents' age ranges from 36 years to 40 years old. Most managers or owners graduated from high school, and some graduated from university. Respondents mostly have approximately 15-year experience in business. $34.09 \%$ of respondents focus on food industry since their businesses are located in villages. These small-medium enterprises have various number of employees. Average full time employees are 11 people, and average part time employees are 13 people. Data show that all samples can be classified as small business (Classification 
of BPS). Most respondents of SMEs production sector have assets ranging from 5 to 50 millions rupiah. Monthly salary are mostly below 50 millions rupiah.

This research instrument was adopted from previous research. All research constructs are measured with five point likert scale $(1=$ almost never to $5=$ almost always). Transformational and transactional leaderships are measured with MLQ1995 (Bass, 1995). Knowledge sharing which includes knowledge collecting and donating dimension are measured by Hoof and Ridder (2004) instrument. Innovation capabilities are measured by Johannessen (2001) instrument.

\section{Research Results}

There are two major tests in this research. First, construct validity (convergent validity and discriminant validity) and hypothesis tests. Two major steps were analyzed with Structural Equation Model (SEM) based on variant or partially least square (PLS) with computer program SmartPLS 2.0. From validity result, it is found that 24 out of 48 items are valid. 24 items were dropped because factor loading score cannot reach minimum valid score 0.5 or has cross loading (Hair et al., 2010). Convergent validity test was done to determine the correlation between the research constructs. Indicators used in convergent validity are factor loading value which accumulated in its construct and AVE values (Hair et al., 2010). Reliability also includes analyzing convergent validity. According to Hair et al. (2010), reliability is one of the convergent validity indicators. Reliability measurement suitable for PLSSEM is composite reliability (Hair et al., 2011). The result of the test can be seen in Table 2.

Table 2. Convergent Validity and Reliability.

\begin{tabular}{llllll}
\hline \multirow{2}{*}{ Variables } & \multirow{2}{*}{$\begin{array}{l}\text { Number } \\
\text { of items }\end{array}$} & \multicolumn{2}{l}{ Convergent validity } & & Composite \\
\cline { 3 - 4 } & 9 & $0,637-0,811$ & 0,567 & 0,886 \\
Transformational leader (TRF) & 9 & $0,775-0,897$ & 0,688 & 0,814 \\
Transactional leader (TRX) & 2 & $0,632-0,758$ & 0,575 & 0,818 \\
\hline Knowledge donating (KD) & 5 & $0,769-0,812$ & 0,630 & 0,871 \\
\hline Knowledge collecting (KC) & 4 & $0,646-0,819$ & 0,587 & 0,849 \\
\hline Innovation capabilities (INOV) & 4 & & &
\end{tabular}

Source: Primary Data (2017).

Table 2 shows that all research variables have loading factor and AVE value bigger than 0,5 (Hair et al., 2010). Composite reliability scores for all variables shown in Table 2 are bigger than 0.7 . It means that composite reliablity for all constructs show the ideal value (Hair et al., 2011). After conducting convergent validity, the researcher analyzes discriminant validity to compare the differences between constructs. Discriminant validity is measured by comparing AVE square root and correlation latent variable (Chin, 1995; Jogiyanto and Abdillah, 2009). Discriminant validity test result can be seen in Table 3 . 
Table 3. Discriminant Validity.

\begin{tabular}{lllllll}
\hline VARIABLES & AKAR AVE & INOV & KC & KD & TRF & TRX \\
\hline INOV & 0,767 & 1 & & & & \\
\hline KC & 0,794 & $-0,081$ & 1 & & & \\
\hline KD & 0,690 & 0,117 & 0,556 & 1 & & \\
\hline TRF & 0,684 & 0,03 & 0,419 & 0,432 & 1 & \\
\hline TRX & 0,829 & 0,081 & 0,259 & 0,287 & 0,629 & 1 \\
\hline
\end{tabular}

Source: Primary Data (2017).

Note: INOV: innovation capabilities, KC: knowledge collecting, KD: knowledge donating, TRF: transformational leadership, TRX: transactional leadership.

Table 3 shows all research contructs posses discriminat validity because AVE square root score is higher than correlation latent variable. It means that every construct has distinctive characteristics. Before hypothesis test, the researcher had conducted Rsquare $\left(\mathrm{R}^{2}\right)$ score, and the result is presented in Table 4 below.

Table 4. Model Prediction.

\begin{tabular}{ll}
\hline Variables & R Square Scores \\
\hline Innovation capabilities (INOV) & 0,046 \\
Knowledge collecting (KC) & 0,175 \\
Knowledge donating (KD) & 0,358 \\
\hline
\end{tabular}

Source: Primary Data (2011).

Table 4 shows that innovation capabilities of SMEs in production sector located in North Sulawesi Province have contributed $4,6 \%$ to knowledge donating and collecting. Other variables and factors largely contribute to knowledge donating and collecting. It means that knowledge sharing is important to increase innovation capabilites, but SMEs at North Sulawesi Province do not focus their concern on that matter. All variables of knowledge sharing $(\mathrm{KC}+\mathrm{KD})$ are influenced by leadership style of the owner of SME by $53.3 \%$ while the rest is influenced by other factors.It can be concluded that leadership style is an important factor to influence knowledge sharing.

Critical ratio (CR) of 1.960 is used to determine whether the hypothesis is significant or not (for level of confidence 95\%). If CR score is above 1,960 and positive, it can be concluded that hypothesis can be accepted and vice versa. The result can be seen in Table 5.

Table 5. Hypothesis Test.

\begin{tabular}{l|l|l|l|l|l}
\hline Hypothesis & Correlation & Coefficient & S.E & C.R & Explanation \\
\hline H1a & TRF $\rightarrow$ KC & 0,423 & 0,085 & 4,941 & Supported \\
H1b & TRF $\rightarrow$ KD & 0,223 & 0,078 & 2,862 & Supported \\
H2a & TRX $\rightarrow$ KC & $-0,006$ & 0,098 & 0,066 & Unsupported \\
H2b & TRX $\rightarrow$ KD & 0,028 & 0,088 & 0,321 & Unsupported \\
\hline
\end{tabular}




\begin{tabular}{l|l|l|l|l|l}
\hline H3 & KC $\rightarrow$ KD & 0,455 & 0,058 & 7,741 & Supported \\
H4a & KD $\rightarrow$ INOV & 0,238 & 0,113 & 2,104 & Supported \\
H4b & KC $\rightarrow$ INOV & $-0,217$ & 0,116 & 1,766 & Unsupported \\
\hline
\end{tabular}

Note: * sig. At 5\%. TRF: transformational leadership TRX: transactional leadership, KC: knowledge collecting, KD: knowledge donating.

Source: Primary Data (2017).

According to Table 5 above this study concludes that hypothesis one (H1a and H1b) is accepted while hypothesis two ( $\mathrm{H} 2 \mathrm{a}$ and $\mathrm{H} 2 \mathrm{~b}$ ) is not accepted. Hypothesis three ( $\mathrm{H} 3 \mathrm{a}$ and $\mathrm{H} 3 \mathrm{~b})$ is accepted while hypothesis four $(\mathrm{H} 4 \mathrm{a})$ is accepted but hypothesis $\mathrm{H} 4 \mathrm{~b}$ couldn't be accepted because there is no significant negative influence knowledge collecting on inovation capabilities.

\section{Discussion}

The research result shows that transformational leadership has a positive influence to encourage knowledge sharing. These results are similar as in the previous study (Wuryaningrat, 2013). Bass (2003), and Yukl (2006) reveal that transformational leadership is more effective than transactional leadership. According to Gorelick et al. (2004), a charismatic, powerful, and passionate leader who has a clear vision and a strong faith as well as becoming role model can be a good leader to develop and manage organization knowledge resources. Those characteristics support transformational leadership.

The results also confirm Bryant's study. Bryant (2003) reveals that transformational leadership has positive effect to influence knowledge sharing activity. The result also confirms that transformational leadership can influence organization life and human from every aspect and organization behavior (Tepper 2000; Northouse, 1997). Leadership transformational is a form of emotional relationship between supervisor and subordinates (Deluga, 1990).

Hence, the connection between the owners of SME and the employees may build emotional relationship. Emotional relationships foster employees' willingness to have open attitude and behavior, so they can share knowledge (Xue et al., 2011).

Other transactional leaderships could not affect knowledge sharing. Previously, SMEs in production sector at North Sulawesi Province are located on the village, and they hire most of their employees from the village too (Table 1). This is possible to build emotional relationship between employees and their leader. Research reveals that a strong emotional bond between employer and employees is possible because the sense of familyhood and friendship at rural areas is still strong. Hence, reward and punishment approach are apparently not the right approaches for the SMEs in production sector at North Sulawesi Province. 
Kohn (1993) reveals that there is correlation between reward and punishment. Kohn (1993) states that reward is made by management as another form of punishment, because sometimes the employees are difficult to predict whether they are punished or awarded with a reward if they fail to achieve target. Kohn (1993) also reveals that reward could impaire the relationship that has been built because it creates unhealthy competition among employees. Hence, transactional leadership style that emphasizes reward and punishment could eliminate the relationship between superior and subordinates.

The third hypothesis supports the research because it gives empirical evidence which show how the owner or manager of SMEs perceives the employees' willingness to donate and collect knowledge. To acquire new knowledge, a manager needs to build intensive understanding and communication with the subordinates and other individuals involving in an organization. This close relationship enables employees and other stakeholders to open themselves and willing to share knowledge. Hoof and Ridder (2004) reveal that knowledge collecting can encourage people's willingness to donate their knowledge.

The following discussion is related to the fourth hypothesis ( $\mathrm{H} 4 \mathrm{a}$ and $\mathrm{H} 4 \mathrm{~b}$ ). The research shows empirical evidence that knowledge donating has a positive influence to SMEs innovation capabilities. Vries et al. (2006) reveal that individuals who are willing to donate their knowledge have desire to be recognized by others. This research indicates that the actor of SMEs in production sector must have attitude, behavior and passion to open up their knowledge. Their attitude, behavior and passion indicate that it could be easier to transform new knowledge on innovation capabilities (Liao et al., 2007).

The research also reveal surprising and unexpected results which show that knowledge collecting gives a negative effect on the innovation capabilities (although there is no empirical evidence). The concept of innovation tunnel (Clark and Wheelright, 1992) can explain these findings. The concept assumes that the amount of knowledge, information and ideas will make a person confused and difficult to determine which relevant knowledge to deliver as innovation.

With knowledge collecting, the owner/manager of SMEs could collect knowledge from many sources including their employees, suppliers and costumers. However, the knowledge gained can trigger a problem such as difficulty and confusion in choosing or absorp relevant knowledge that can be used to make innovation.

SMEs are the business sector which has many shortages such as low education level, lack of capital and lack of technology. That shortage probably be caused of knowledge were created could not absorb well. Liao et al. (2007) explains that low education level will cause low knowledge absorptive capacity. Besides, SMEs in production sector usually operate based on order. Thus, the innovation ability is weak because many customers order the products based on their personal preference. 


\section{Conclusion}

This study proves that the transformational leadership style has a positive effect on knowledge sharing activities. It can be summarized that transformational leadership style plays an important role as compared to transactional leadership in developing knowledge sharing activities in the SMEs in production sector at North Sulawesi Province. Transformational leadership style enable the owners or managers of SMEs in production sector at North Sulawesi Province to encourage the involvement of employees to work together to foster innovation. Transformational leadership is characterized by nurturing, educating, guiding, motivating attitudes and becoming a role model. Thus, these characteristics can be used to encourage attitudes, behaviors and motivation of the employees to share knowledge.

Based on this research, it can be concluded that knowledge-sharing activities require good and intensive communication. This communication is useful to create better close relationship between the owner and employees. It is expected that more individuals will be more open to knowledge. Knowledge sharing is an important element in knowledge management (Srivastava, 2006). The results of this study provide empirical evidence that the dimension of knowledge sharing has a positive effect on the innovation capabilities, while the dimension of knowledge collecting gives a negative impact on innovation capability. To sum up, the activities play an important role in increasing innovation capability. Knowledge collecting can be used to increase the knowledge donating activity.

Knowledge colleting has a negative influence on the innovation ability due to the difficulties in absorbing knowledge. It results from the inadequate number of qualified human resources, low capital level, and low technology mastery. To overcome the problems, various parties such as government need to enhance its role to enhance the innovation capabilities of SMEs.

This research has succeeded to answer research objectives. The results of this study show that the leadership of the owners or managers of SMEs plays important role to encourage the creation of knowledge-sharing activities. Knowledge sharing activities can also generate new knowledge that can be used by SMEs to increase innovation capabilities.

The results of this study also show that the expected development of SME may be a reflection to the owners or managers to further strengthen their leadership role. Thus, small-medium sized enterprises can develop better cooperation with the employees and all business elements. Eventually, knowledge sharing can be maintained in order to keep up with information, new ideas, new skills, which in turn makes SMEs more innovative. 
The research has similar results as those of Wuryaningrat's study (2012) because the characteristics of SMEs are basically not different regardless of the cultural differences. In other words, culture is not the important issue in this research.

\section{Limitations and Suggestions}

Cross sectional survey method could be justifable as a research limitation. Leadership is changeable through time; thus, next research can consider longitudinal survey research method. This research uses subjective perspective from the owners of SME which could result in biases, so the next research should include objectivity. For example, patent-based measuring innovation can be considered. Next research can include absorbtive capacity, personality, and personal organization to find a better understanding about how innovation can be increased through knowledge sharing. That variables can be justified as moderating variables or mediating variables.

\section{References:}

Acs, Z.J., Morck, R., Shaver, J.M. and Yeung, B. 1997. The Internationalization of Small and Medium-Sized Enterprises: A Policy Perspective. Small Business Economics, 9, 7-20.

Appleyard, M.M. 1996. How does knowledge flow? Interfirm patterns in the semi-conductor industry. Strategic Management Journal,17, 137-154.

Argote, L., McEvily, B. and Reagans, R. 2003. Managing knowledge in organizations: an integrative framework and review of emerging themes. Management Science, 49(4), 571-582.

Ayyagari, M. 2006. Micro and small enterprises: unexplored pathways to growth. USAID working paper. The Iris Center, University of Maryland.

Bagozzi, R.P. and Dholakia, U.M. 2002. Intentional Social Action in Virtual Communities. Journal of Interactive Marketing, 16(2), 2-21.

Barney, J. 1991. Firm resources and sustained competitive advantage. Journal of Management, 17(1), 99-120.

Bartol, K.M. and Srivastava, A. 2002. Encouraging knowledge sharing: the role of organizational reward system. J. of Leadership \& Organizations Studies, 9(1), 64-76.

Bass, B.M., Avolio, B.J., Jung, D.I. and Berson, Y. 2003. Predicting Unit Performance by Assessing Transformational and Transactional Leadership. Journal of Applied Psychology, 88(2), 207-218.

Bock, G.W. and Kim, Y. 2002. Breaking the myth of reward: an exploratory study of attitude about knowledge sharing. Information Resources Management Journal, 15(2), 14-21.

Bryant, S.E. 2003. The role of transformational and transactional leadership in creating, sharing, and exploiting knowledge. J. of Leadership \& Organizational Studies, 9(4), 32-44.

Clark, K.B. and Wheelwright, S.C. 1992. Managing New Product and Process Development. New York, Free Press.

Cooper, D.R. and Schindler, P.S. 2010. Business Research Methods, $10^{\text {th }}$ Edition. Singapore, McGraw-Hill.

Covin, J.G. and Miles, M.P. 1999. Corporate Entrepreneurship and the Pursuit of Competitive Advantage. Entrepreneurship: Theory and Practice, 23, 105-120. 
Crawford, C.B. 2005. Effects of Transformational Leadership and Organizational Position on Knowledge Management. Journal of Knowledge Management, 9(6), 6-16.

Dalkir, K. 2005. Knowledge Management in Theory and Practice. UK, Burlington, MA.

Damanpour, F. 1996. Organizational complexicity and innovation: developing and testing multiple contingency models. Management science, 42(5), 1422-1433.

Darroch, J. 2005. Knowledge Management, innovation, and firm performance. Journal of Knowledge Management, 9(3), 101-115.

Davenport, T.H. and Prusak, L. 1998. Working Knowledge: How Organizations Manage What They Know. Harvard Business School Press, Boston, MA.

Deluga, R.J. 1990. The effect of transformational, transactional and laissez faire leadership on subordinate influencing behavior. Applied Social Psychology, 11(2), 191-203.

Du Plessis, M., 2007. The role of knowledge management in innovation. Journal of Knowledge Management, 11(4), 20-29.

Dyer, J.H. and Nobeoka, K. 2000. Creating and managing a high-performance knowledge sharing network: The Toyota case. Strategic Management Journal, 21(3), 345-368.

Gorelick, C., Milton, N. and Apri, K. 2004. Performance Through Learning: Knowledge Management in Practice. USA, Elesevier.

Grant, R.M. 1996. Toward a knowledge-based theory of the firm. Strategic Management Journal, 17, 109-122.

Hair, J.F, Sarstedt, M., Ringle, C.M. and Mena, J.A. 2011. An assessment of the use of partial least squares structural equation modeling in marketing research. Journal of Academic of Marketing Science, 10, 1-20.

Hair, J.F., Tatham, A.R.L. and Black, W.C. 2010. Multivariate Data Analysis: Global Perspective, $7^{\text {th }}$ edition. New Jersey. Prentice Hall.

Harrison, N. and Samson, D. 2002. Technology Management. New York, McGraw Hill.

Indarti, N. 2010. The Effect of Knowledge Stickiness and Interaction on Absorptive Capacity: Evidence from furniture and software Small and Medium Enterprises in Indonesia. Unpublished PhD thesis,University of Groningen, Groningen, Netherlands.

Johannessen, J.A., Olsen, B. and Lumpkin, G.T. 2001. Innovation as newness: What is new, how new, and new to whom? European J. of Innovation Management, 4(1), 20-31.

Kamasak, R. and Bulutlar, F. 2010. The influence of knowledge sharing on innovation. European Business Review, 22(3), 306-317.

Kluge, J., Stein, W. and Licht, T. 2001. Knowledge Unplugged. Bath Press, Bath.

Koh, W.L., Steers, R.M. and Terborg, J.R. 1995. The Effect of transformational leadership on teacher attitudes and student performance in Singapore. Journal of Organizational Behavior, 16(4), 319-333.

Kohn, A. 1993. Why Incentives Plans Cannot Work. Harvard Bussiness Review, 54-63.

Lam, A. and Lambermont-Ford, J.P. 2010. Knowledge sharing in organizational contexts: a motivation-based perspective. Journal of Knowledge Management, 14(1), 51-66.

Liao, S., Fei, W.C. and Chen, C.C. 2007. Knowledge sharing, absorptive capacity, and innovation capability: an empirical study of Taiwan's knowledge intensive industries. Journal of Information Science, 33(3), 340-359.

Lin, H. 2007. Knowledge sharing and firm innovation capability: an empirical study. Journal of Manpower, 28(3), 315-332.

March, J.G. 1991. Exploration and exploitation in organizational learning. Organization Science, 2(1), 71-87.

Mintzberg, H, 1973. The Nature of Managerial Work. New York, Harper \& Row.

Nonaka, I. and Takeuchi, H. 1995. The Knowledge-Creating Company: How Japanese Companies Create the Dynamics of Innovation. New York, Oxford University Press. 
Nonaka, I., Von Krogh, G. and Voelpel, S. 2006. Organizational knowledge creation theory: Evolutionary paths and future advances. Organization Studies, 27(8), 179-208.

Northouse, P.G. 1997. Leadership: Theory and Practices. Sage Publication, USA.

Pelham, A.M. 2000. Marketing orientation and other potential influences on performance in small and medium-sized manufacturing firms. Journal of Small Business Management, 38(1), 48-67.

Pirich, A., Knuckey, S. and Campbell, J. 2001. An interface between entrepreneurship and innovation: New Zealand SMEs perspective. DRUID Nelson and Winter Conference.

Politis, J.D. 2004. Transformational and transactional leadership predictors of the 'Stimulant' determinants to creativity in organisational work environments. Electronic Journal of Knowledge Management, 2(2), 23-34.

Robbins, S.P. 2001. Organizational Behavior. Prentice Hall International, Inc.

Rogers, E.M. 2003. Diffusion of innovations. New York, Free Press.

Singh, S.K. 2008. Role of leadership in knowledge management. Journal of Knowledge Management, 12(4), 3-15.

Srivastava, A., Bartol, K.M. and Locke, E.A. 2006. Empowering leadership in management teams: Effects on knowledge sharing, efficacy, and performance. Academy of Management Journal, 49, 1239-1251.

Sveiby, K. 2001. A knowledge based theory of the firm to guide in strategy formulation. Journal of Intelectual Capital, 2(4), 344-358.

Szulanski, G. 2000. The process of knowledge transfer: A diachronic analysis. Organizational Behavior and Human Decision Process, 82(1), 9-27.

Szulanski, G. 1996. Exploring internal stickness: Impediments to the transfer of best practice within the firm. Strategic Management Journal, 17, 27-43.

Tepper, B. 2000. Consequences of abusive supervision. Academy of Management Journal, 42(2), 178-190.

Tidd, J. and Bessant, K. 2005. Managing Innovation: Integrating Technological, Market and Organizational Change. Chichester, John Wiley \& Sons.

Tsai, W. 2001. Knowledge transfer in intraorganizational network: Effect of network position and absorptive capacity on business unit innovation and performance. Academy of Management Journal, 44(5), 996-1004.

Van den Hooff, B. and de Ridder, J.A. 2004. Knowledge sharing in context: the influence of organizational commitment, communication climate and CMC use on knowledge sharing. Journal of Knowledge Management, 8(6), 117-130.

Vries, R.E., Van de Hooff, B. and de Ridder, J.A. 2006. Explaining Knowledge Sharing: The Role of Communiction Styles, Job Satisfaction, and Performance Belief. Communication Research, 33(2), 115-135.

Wiklund, J. and Shepherd, D. 2003. Knowledge-based resources, entrepreneurial orientation and the performance of small and medium-sized businesses. Strategic Management Journal, 24(13), 1307-1314.

Wuryaningrat, N.F. 2013. Knowledge Sharing, Absorptive Capacity and Innovation Capabilities: Empirical Study on Small Medium Entreprises at North Sulawesi, Indonesia. Gadjah Mada International Journal of Business, 15(1), 61-77.

Xue, Y., Bradley, J. and Liang, H. 2011. Team Climate, Empowering leadership, and Knowledge Sharing. Journal of Knowledge Management, 15(2), 299-312.

Yeh, C.M., Hu, H.N. and Tsai, S.H. 2010. A Conceptual Model of Knowledge Sharing and Market Orientation in the Tourism Sector. American Journal of Applied Sciences, 8(2), 343-347.

Yukl, G. 2006. Leadership in Organizations, $6^{\text {th }}$ edition. New Jersey, Prentice Hall. 